\title{
A Tracer Study on the Graduates of Guidance and Counseling Department of Ahmad Dahlan University
}

\author{
Sri Hartini \\ Department of Guidance and Counseling \\ Ahmad Dahlan University \\ Yogyakarta, Indonesia \\ sri.hartini@bk.uad.ac.id \\ Caraka Putra Bhakti \\ Department of Guidance and Counseling \\ Ahmad Dahlan University \\ Yogyakarta, Indonesia \\ caraka.pb@bk.uad.ac.id
}

\author{
Dody Hartanto \\ Department of Guidance and Counseling \\ Ahmad Dahlan University \\ Yogyakarta, Indonesia \\ dody.hartanto@bk.uad.ac.id
}

\begin{abstract}
This tracer study aims to describe users alumni evaluation towards the graduates of Guidance and Counseling Department. This study belongs to the quantitative descriptive study applying survey approach. This study employs random sampling technique with $30 \%$ proportion of the total graduate during 2014-2016. This study uses primary data which are obtained directly from the alumni and the users of alumni by using structured questionnaires. The questionnaires are distributed directly to the tracked graduates and the users of alumni. The users of alumni consider that the competence of the graduates of guidance and counseling courses in terms of the aspects of integrity, professionalism, IT usage, communication, teamwork, and self-development are very good, but it still lacks in the use of language, especially English. This research recommends policy development on English ability improvement program through the use of foreign literature in lectures, establishment of English Club and TOEFL training in cooperation with English Education Study Program, and UAD Language Development Center Institution.
\end{abstract}

Keywords_-Graduates' performance, guidance, counseling

\section{INTRODUCTION}

College as a place for developing professional experts always tries to study this problem continuously. College or higher education according to the National Education System Law of 2003 Higher education is education after education which includes diploma, undergraduate, master, specialist and doctoral education programs organized by universities [1].

Higher education considers education as a product, rather than completely forgetting the problem of product quality. The real quality of education lies in the ability of science to be applied in society and the ability of science to improve the quality of life. The notion that the essence and basis of existence is essential to the establishment of a college and the formation of scientific alliances based on a passion for knowing, developing, and practicing the science of knowledge for the advancement of civilization of society [2].

Graduates' quality becomes the main problem concerning the competitiveness of graduates in universities. The quality of the graduates is also caused by the quality factor of educators (lecturers), educational facilities, infrastructure, and the college policy. These three things are the crucial causes to support the quality of graduates in universities. The quality of graduates will enhance the competitiveness of these graduates personally and the college concerned. The success of an institution in producing graduates, in this case the Institution of Teachers Educators Teachers (LPTK), can be seen from the extent to which the graduates can practice science in the field of the community. This is in line with one of the objectives of learning so that students can be useful in contributing science expertise in accordance with the field. In general, the implementation of universities in Indonesia aims to prepare human resources who can professionally apply and develop their areas of expertise and able to disseminate and seek the use of expertise to improve the standard of living of the community and national culture.

To be able to see the extent to which graduates of guidance and counseling courses can benefit the community, it is necessary to do a study / a study tracking (tracer study). Tracking studies include: where the graduates are currently, in what areas of the graduates work, to what extent the graduates are perceived to be beneficial by the stakeholders, does the provision of the graduates is appropriate to the needs of the community, are there any shortcomings during the graduates devoting their knowledge, how long the graduates wait to get a job, how much income / early salary work, is there any training that is done in work. Tracer study can provide information for the purpose of evaluation of higher education outcomes and can then be used for improvement and quality assurance of higher education institutions [3]. Tracer study 
also provides valuable information on the relationship between higher education and professional work, assessing the relevance of higher education, information to stakeholders, and the completeness of the requirements for higher education accreditation.

Graduate tracer studies are one form of empirical study that can appropriately provide valuable information for evaluating the results of the education and training of a specific institution of higher education.[4]. Meanwhile, a study showed that the results of the tracer study are needed by every college to know the success of the educational process that has been done to the students, so it needs to be done periodically [5].

The importance of the tracer study is as follows: "By conducting a survey on the cohort of graduates from a specific institution, profession, discipline, level of education, their employment characteristics, competencies and skills development, and have a comparative analysis, the information gained from these can be used by the graduate's alma mater and other education stakeholders for curriculum development and other emerging reforms [6]. In addition, currently tracer study has been made one of the requirements of completeness of accreditation in Indonesia by the National Accreditation Board of Higher Education.

Graduates themselves are the status achieved by students after completing the education process in accordance with the graduation requirements set by the college. As one of the direct outputs of the educational process undertaken by universities, qualified graduates possess academic competence, including hard skills and soft skills as stated in the quality objectives and are proved by the performance of graduates in the community in accordance with the profession and the field of science [7].

There are two skills needed to enter the working world of basic knowledge / skills and applied skills. Applied skills that are needed are: 1) critical thinking/ problem solving; 2) oral communications; 3)written communications; 4) teamwork/ collaboration; 5) diversity; 6) information technology application; 7) leadership; 8) creativity/ innovation; 9) lifelong learning/self direction; 10) professionalism/work ethic; and 11) ethics/ social responsibility [8].

Counselors are professionals, meaning that they have been formally prepared through authorized institutions of educational institutions. They are not specifically trained to gain competence as counselors that include knowledge, attitudes, personality and experience in the field of counseling and guidance. The complete figure of the counselor's competence includes academic competence and professional competence [9]. Academic competence is the scientific foundation of the implementation of professional services of guidance and counseling. The integrated academic and professional competence of counselors builds pedagogic, personality, social competence. Academic and professional competence is formed to conduct learning activity on education which is structured in the form of curriculum of study program especially guidance and counseling.
The guidance and counseling study program of Teacher Training and Education Faculty of Ahmad Dahlan University is one of the leading programs at UAD. One of the general goals of guidance and counseling programs is to produce professionals in the field of guidance and counseling services. The development of graduate quality continues to be done with the spirit of continuous improvement. The important activities undertaken are to improve the curriculum of the study program that refers to the needs of graduate users. So what needs to be done is to capture comprehensive information from alumni and users.

Based on the background above, the researchers are interested in conducting a tracer study. In addition, the tracer study plan can also be used as a feedback for guidance and counseling programs to evaluate and improve the curriculum so graduates can accommodate community needs / demands.

\section{METHODS}

\section{A. Data Source}

There are two sources of the research data, namely bibliographic sources in the form of a number of bibliographies (literature, books, and journals) that are directly related to the theme of this research, and field data obtained through questionnaires and observations on progress and achievement of undergraduate program alumni. The primary source of this research data is the questionnaire distributed to the respondents. While secondary source of this research data is the result of observation and reading to some relevant literature to research theme. Primary data sources are treated as the focus of data analysis and as a basis for conclusion. Secondary data sources are used to complement and enrich data analysis. Both data sources are read in an integrative way.

\section{B. Research Approach}

The approach used in this research is a combination of quantitative and qualitative approaches. The quantitative approach is used to understand the numerical data obtained from questionnaires to respondents, which are then processed and analyzed using the statistical formula of the central tendency of frail distribution. While the qualitative approach used to understand the qualitative data from the results of observation and interviews with a number of respondents. In this context, researchers position themselves as "instruments" that immediately wrestle and understand the object being studied closely. The method used in this research is survey method, especially in capturing respondents as data source. In the presentation of data, this research uses descriptive analytical method, which describes the results of research obtained from a survey on the performance assessment of alumni of UAD Guidance and Counseling Program, and analyzed it comprehensively, combining the frequency distribution data with the results of research. 


\section{Research Scopes}

The scopes of the research on alumni profile of UAD Guidance and Counseling Program that have been developed into seven aspects are:

1. Integrity (ethics and morals)

2. Expertise based on the field of science (professionalism)

3. English language skills

4. Ability to use information technology

5. Communication skills.

6. The ability of teamwork

7. Self-development capabilities [7]

\section{Population and Sample}

The population in this research is alumni of UAD Guidance and Counseling Program. While sampling method by random, with proportion $30 \%$ proportionally in accordance with the number of graduates during the year 2014-2016.

\section{E. Data Collection Technique}

To collect data and information from alumni, the researchers distribute questionnaires to alumni of UAD Guidance and Counseling program. The questionnaire instrument used is an adoption of the standard tracer study developed by the National Accreditation Board covering seven capabilities including Integrity (ethics and morals), Expertise based on the field of science (professionalism), English, Use of Information Technology, Communication, Teamwork, and Self Development.

\section{F. Processing Technique and Data Analysis}

After the data collected, quantitative data processing is done in the following ways:

1. Editing, all questionnaires are checked for completeness after the respondents fill out the questionnaires.

2. Coding and data entry, done by using SPSS program.

3. Data cleaning, the data have been checked and then rechecked to make sure the data have been cleared of errors, so that each datum is ready to be analyzed. The data then processed and analyzed by SPSS.

\section{RESULT AND DISCUSSION}

Based on the questionnaire dissemination to the users of alumni of UAD Guidance and Counseling Program, the following results are obtained:

\begin{tabular}{|c|c|c|c|c|c|}
\hline \multirow{3}{*}{ No. } & \multirow{3}{*}{$\begin{array}{c}\text { Kind Of } \\
\text { Ablity }\end{array}$} & \multicolumn{4}{|c|}{ The User Respons } \\
\hline & & $\begin{array}{l}\text { Very } \\
\text { Good }\end{array}$ & Good & Enough & Less \\
\hline & & $(\%)$ & $(\%)$ & $(\%)$ & $(\%)$ \\
\hline (1) & (2) & (3) & (4) & (5) & (6) \\
\hline 1 & $\begin{array}{l}\text { Integrity } \\
\text { (ethics and } \\
\text { morals) }\end{array}$ & $93,33 \%$ & $6,67 \%$ & 0 & 0 \\
\hline
\end{tabular}

Table, Cont.

\begin{tabular}{|c|c|c|c|c|c|}
\hline 2 & $\begin{array}{l}\text { Expertise } \\
\text { based on the } \\
\text { field of } \\
\text { science } \\
\text { (professionali } \\
\text { sm) }\end{array}$ & $80 \%$ & $20 \%$ & 0 & 0 \\
\hline 3 & English & $6,67 \%$ & $70 \%$ & $23,33 \%$ & 0 \\
\hline 4 & $\begin{array}{l}\text { Use of } \\
\text { Information } \\
\text { Technology }\end{array}$ & $73,33 \%$ & $26,67 \%$ & 0 & 0 \\
\hline 5 & $\begin{array}{l}\text { Communicati } \\
\text { on }\end{array}$ & $93,33 \%$ & $6,67 \%$ & 0 & 0 \\
\hline 6 & Teamwork & $90 \%$ & $10 \%$ & 0 & 0 \\
\hline 7 & $\begin{array}{l}\text { Self- } \\
\text { Development }\end{array}$ & $86,67 \%$ & $13,33 \%$ & 0 & 0 \\
\hline & Total & $523,33 \%$ & $153,34 \%$ & $23,33 \%$ & $\%$ \\
\hline
\end{tabular}

Based on the table above, it obtained information that the undergraduate alumni of UAD Guidance and Counseling has the integrity (ethics and morals) $93.33 \%$ are in category very good $6.67 \%$ are in good category. The result shows alumni of undergraduate program of guidance and counseling can show the integrity of its performance.

In the aspect of expertise based on the field of science (professionalism), 80\% are in very good category and $20 \%$ are in good category. This result shows that $80 \%$ of alumni according to user ratings can demonstrate expertise in carrying out counseling and guidance services very well. The formation of academic competence of this counselor is the formal education process of undergraduate level (S-1) in the field of guidance and counseling, which leads to the conferment of academic certificate of Bachelor of Education (S.Pd) in the field of Guidance and Counseling. The whole figure of counselor competency covers academic and professional competence as one whole. Academic competence is the scientific foundation of the tips of the implementation of professional services of guidance and counseling. Academic competence is the foundation for the development of professional competence, including: (1) deep understanding of the counselee served, (2) mastering the theoretical framework and guidance counseling, (3) providing counseling and guidance services, and (4) developing Personal and professional counselors [10].

Then, on English ability aspect, $6.67 \%$ are in very good category, $70 \%$ are in good category, and $23.33 \%$ are in enough category. These results indicate that the alumni's English abilities are on the good category so it needs to increase this competence. On the aspect of the ability of the use of information technology, $73.33 \%$ are in very good category and $26.67 \%$ are in the good category. These results indicate that the undergraduates of UAD guidance and counseling courses can use information technology very well in the 
implementation of guidance and counseling services. One of the important challenges of counselor competence in the $21^{\text {st }}$ century is the ability to master information technology in school counseling practice [11].

Furthermore, in relation to communication skills, UAD graduates of $93.33 \%$ UG Guidance and Counseling Program are in very good category and $6.67 \%$ are in good category. This result indicates that $\mathrm{S} 1$ graduates of guidance and counseling can use information technology very well in the implementation of guidance services and counseling. Communication is one of those skills in counseling that are importantly mastered [12]. In the aspect of team cooperation ability, $90 \%$ of UAD Guidance and Counseling Program graduates are in very good category and $10 \%$ are in good category. The important ability of counselor in 21 st century is teamwork and collaboration with various parties [13].

In the aspect of self-development capability, $86.67 \%$ graduates of UAD Guidance and Counseling Program are in very good category and $13.33 \%$ are in good category. This result shows alumni of undergraduate program of guidance and counseling can do self development in developing counseling and guidance. One of the competencies of professional counselors is to conduct self-development on an ongoing basis [10]. The forms of self-development are like attending seminars, workshops, developing appropriate technology, as well as advanced studies at the postgraduate level [14].

\section{CONCLUSION AND RECOMMENDATION}

Higher education considers education as a product, rather than completely forgetting the problem of product quality. The real quality of education lies in the ability of science to be applied in society, the ability of science to improve the quality of life.

Graduates' quality becomes the main problem concerning the competitiveness of graduates in universities. The quality of the graduates is also caused by the quality factor of educators (Lecturers), educational facilities and infrastructure, and also the college policy. These three things are the crucial cause to support the quality of graduates in universities. The quality of graduates will enhance the competitiveness of these graduates personally and the college concerned.

Based on the results of the above research, the researchers recommend some follow-up steps to improve the graduates' ability of UAD Guidance and Counseling program study for next period. First, the existence of character building activities through the provision of ethical material of good and polite dress, and the holding of courses ethics and profession Guidance and Counseling.

Second, the activity of improving the quality of lectures by way of expert involvement in public lectures, first lectures or as guest lecturers; Strengthening lecture material through apprenticeship in school institutions, as well as the need for training program of Guidance and Counseling program and
Scientific Discussion with Peer Counselor and on Guidance and Counseling Management in School.

Thirdly, there is an English language improvement program through the use of foreign literature in the lecture, the establishment of English Club and TOEFL training in cooperation with English Education Study Program and UAD Language Development Center Institute.

Fourth, that is the need to increase the ability of technology use through training of media development and guidance counseling and strengthening of the material in the course of Information Systems and Technology Services Guidance and Counseling.

The fifth follow-up recommendation, namely the improvement of communication skills through interpersonal communication courses and counseling skills, public speaking training, and communication training through classical guidance and group counseling practice.

Then, the sixth is the effort to improve leadership skills and cooperation in the team, that is through basic leadership training activities, group lecture assignments, research activities of collaboration system between lecturers and students, and student involvement in the workshop activities, seminars, public lectures.

The seventh is the further recommendation relating with the ability of self-development. Improvement of selfdevelopment capability is done by scientific writing workshop, workshop on latest counseling technique, and giving information about renewal of guidance and counseling education curriculum.

\section{ACKNOWLEDGMENT}

Publication of the presented results has received funding from Featured Research Programs from Research and Development Institute of Ahmad Dahlan University. This study's content is part of a graduates performance's study of guidance and counseling department Ahmad Dahlan University.

\section{REFERENCES}

[1] Undang-Undang Nomor 20 Tahun 2003 tentang Sistem Pendidikan Nasional

[2] Marwata. "Eksistensi Perguruan Tinggi Swasta”. Diunduh dari http://cetak.kompas.com/read/2009/10/14/11011932/eksistensi.pergurua n.tinggi.swasta/.2009.

[3] Kemendikbud. Buku Panduan Sistem Pusat Karir. Jakarta: Dirjen Pembelajaran dan Kemahasiswaan, Kemendikbud. 2012.

[4] Schomburg, Harald. Handbook for Graduate Tracer Studies. Deutsche Gesellschaft für Technische Zusammenarbeit (GTZ) GmbH. Retrieved from http://www.uni-kassel. 2003. 
[5] Roviati, Evi dkk. Tracer Study: Studi Rekam Jejak Alumni dan Respons Stakeholder Jurusan Tadris IPA-Biologi IAIN Syekh Nurjati Cirebon. Scientia Educatia Journal. Vol. 5, No. 1, 2015.

[6] Gines, Adelaida C. Tracer Study of PNU Graduates. American International Journal of Contemporary Research Vol. 4, No. 3, March 2014.

[7] Tinggi, B. A. N. P. Buku I Naskah Akademik Akreditasi Program Studi Sarjana. Jakarta: Departemen Pendidikan Nasional. 2008.

[8] Casner-Lotto J. and L. Barrington. 2006. Are they really ready to work Employers' Perspectives on the Basic Knowledge and Applied Skill of New Entrants to the 21st century U.S. The Conference Board, Inc., the Partnership for21st Century Skills, Corporate Voices for Working Families, and the Society for Human Resource Management. Printed in the U.S.A.

[9] Peraturan Menteri Pendidikan Nasional Nomor 27 Tahun 2008.

[10] Depdiknas. Penataan Pendidikan Profesional Konselor dan Layanan Bimbingan dan Konselingdalam Jalur Formal. Jakarta: Depdiknas. 2008.

[11] Schmidt, J. J. Counseling in Schools: Essential Services and Comprehensive Programs. Allyn \& Bacon. 2008.

[12] Fernando, S. Communication skills and counselling. Sri Lanka Journal of Obstetrics and Gynaecology, 34(2). 2012.

[13] Paisley, P. O., \& McMahon, G. School counseling for the 21st century: Challenges and opportunities. Professional School Counseling, 5(2), 106-116. 2001.

[14] Kartadinata, S. Menguak Tabir Bimbingan dan Konseling sebagai Upaya Pedagogis. Bandung: UPI Press. 2011.

[15] Aquino, Anania B., dkk. Tecaher Education Graduate Tracer Study from2010 TO 2014 IN One State University in Batangas, Philippines. Asia Pasific Journal of Multidisciplinary Research. Vol. 3, No. 5, Part II, December 2015.

[16] Mayang, Sthepanie, dkk. Evaluasi Tracer Study Untuk Pembelajaran dengan Pendekatan Ergonomi Makro. Jurnal Teknik Industri, Vol. 1, No. 4, pp. 284-288, Desember 2013. 